\title{
The Development of New Material for Food Production Package in Indonesia: Proposed Key Success Factors
}

\author{
Nyayu Lathifah Tirdasari \\ School of Business \\ IPB University \\ Bogor, Indonesia \\ nyayu.lathifah@apps.ipb.ac.id \\ Dikky Indrawan \\ School of Business \\ IPB University \\ Bogor, Indonesia \\ rdikky@apps.ipb.ac.id
}

\begin{abstract}
Nowadays, it is important to reduce and replace plastic in the food manufacture industry. However, the development of new material is less than satisfactory. This paper aims to analyze the key factors for the development of new material for the food production package. A survey was conducted to gather data to test the factors in the development of new material for food production package identified by literature review, expert interviews, and distribution questionnaires to respondents. The questionnaire uses a Likert scale and the cluster sampling method. The analytical tool used is factor analysis. The results show that the key success factors are different from the developed country. The government was expected to have a significant effect on the development of new material, the public or consumer placed second.
\end{abstract}

Keywords: new material, food package, key success factor

\section{INTRODUCTION}

The packaging industry nowadays depends on plastics, which raises worries about the future in terms of both economy and environment. Reducing and replacing plastic in food manufacturing is very important. However, the development of new material is less than satisfactory since the process is very complex. Currently, the world is looking for solutions for packaging, which is more sustainable for economics and society [1]. Indonesia is ranked as the second country in the world with the largest plastic waste after China [2]. The biggest contributor to this waste is the non-biodegradable plastic packaging utility and the unavoidable use of plastic in daily life as well. An issue of particular consideration is that wasted plastic reaches 26,500 tons per day in Indonesia [3]. The waste causes carbon storage reduction of the seas as well as severe damage to many living things. Therefore, the development of new material for packaging is necessary.

Food and beverage packaging industries that concern about the issue of global warming have started to use environmentally friendly packaging, or what is

\author{
Andina Oktariani \\ School of Business \\ IPB University \\ Bogor, Indonesia \\ andina.oktariani@apps.ipb.ac.id \\ Nur Hasanah * \\ School of Business \\ IPB University \\ Bogor, Indonesia \\ nur.hasanah@apps.ipb.ac.id
}

commonly referred to as sustainable packaging [4]. In order to substitute conventional plastics, utilization of wood is an effective material for packaging. Paper is one of the most popular packaging products derived from wood. Indonesian government demand is that each industry obliged to reduce the volume of plastic waste produced. Furthermore, in order to reduce the accumulation of plastic waste in Indonesia, industries across the country are expected to implement a sustainable system of plastic waste management [5].

This study aims to propose the key success factors for the development of new material for food production package in Indonesia. It is also an effort to elaborate on the potential of new material for food packaging. This paper covers the factors presented by several works of literature. Another intention of this paper is to give attention to the plastic waste output in Indonesia.

\section{MATERIALS AND METHODS}

This study will make use of survey methodology to test the factors in the development of new material for food production package which has been previously identified through literature review and expert interviews. This research distributed questionnaires to respondents. The questionnaire uses a Likert scale and the cluster sampling method. The analytical tool used is factor analysis. The research question is investigating the key success factors for the development of new material for food production package in Indonesia.

The initial concept of this research was conceived from the indicator of key success factors for both development and participation [1]. The literature on success factors for bio-based packaging has highlighted several indicators of key success factors for development. These indicators include technical substitution, technical drivers/barriers, application barriers, cost barriers, and raw material supply barriers. This research measures the level of importance each indicator is influential for developing new materials. 
The indicators of key success factors for participation consists of five dimensions, which are government behavior, public characteristics, company characteristics, and external environmental conditions. Each dimension can be listed as two to eight factors, as described in Table 1. These indicators are used to capture response, support, or awareness from each party towards new materials development.

TABLE 1. INDICATORS OF KEY SUCCESS FACTORS FOR PARTICIPATION

\begin{tabular}{|c|c|}
\hline Dimension & Factors \\
\hline $\begin{array}{l}\text { Government } \\
\text { behavior }\end{array}$ & $\begin{array}{l}\text { - Convenience and smoothness of participation } \\
\text { - Inform the public of the scope of participation } \\
\text { and its timeliness } \\
\text { - Substantive participation } \\
\text { - The capabilities of coordinating different } \\
\text { stakeholders } \\
\text { - Timeliness, comprehensiveness and authenticity } \\
\text { of information disclosure } \\
\text { - Timeliness and rationality of feedback to public } \\
\text { opinions } \\
\text { - Government officials' awareness and ability } \\
\text { - Degree of administration according to law }\end{array}$ \\
\hline $\begin{array}{l}\text { Public } \\
\text { characteristics }\end{array}$ & $\begin{array}{l}\text { - Participation competence (communication } \\
\text { expression, organization alliance, etc.) } \\
\text { - Knowledge level (the necessary knowledge and } \\
\text { common sense for decision-making) } \\
\text { - Equality of discourse rights of vulnerable groups } \\
\text { - Participation willingness/enthusiasm } \\
\text { - Participation of other public entities } \\
\text { (associations, organizations, experts, etc.) } \\
\text { - Interaction between participants }\end{array}$ \\
\hline $\begin{array}{l}\text { Company } \\
\text { characteristics }\end{array}$ & $\begin{array}{l}\text { - Emphasis on public participation } \\
\text { - Purity and transparency between officials and } \\
\text { businessmen }\end{array}$ \\
\hline $\begin{array}{l}\text { External } \\
\text { environmental } \\
\text { conditions }\end{array}$ & $\begin{array}{l}\text { - Introduction of national relevant laws and } \\
\text { regulations } \\
\text { - Social supervision and restraint } \\
\text { - Awakening of social democratic consciousness } \\
\text { - News coverage and publicity of related events }\end{array}$ \\
\hline
\end{tabular}

\section{DISCUSSION}

This research focuses on exploring the key factors which affect the effectiveness of external participation in the development of new material for food production package in Indonesia. Before identifying the key factors, it is necessary to perceive the actual condition for developing new materials for food packages in Indonesia. The main factors which affect the external participation attributed to four main dimensions. Firstly, government behavior. Secondly, public characteristics. Thirdly, the company characteristics. And lastly, the external environmental conditions. Specific indicators for each dimension are given in Table 1.

Based on theoretical analysis and expert interviews, this study assumes that there is a relationship between the latent variables. Thus this paper forms a theoretical framework of structural models and proposed four hypotheses as follows:

H1: Government behavior has a positive and significant impact on the effectiveness of developing new material for food package.
H2: Public characteristics have a positive and significant impact on the effectiveness of developing new material for food package.

H3: Company characteristics have a positive and significant impact on the effectiveness of developing new material for food package.

H4: External environmental conditions have a positive and significant impact on the effectiveness of developing new material for food package.

Survey is conducted to test each factor identified by the literature review and expert interviews. This research distributes the questionnaire to respondents. The questionnaire uses a Likert scale, and the respondents are chosen based on the cluster sampling method. This study uses factor analysis and Cronbach's alpha tool. Cronbach's alpha uses to analyze reliability. Reliability is the measure of the extent to which the same outcome can be gained by repeating the same procedure adopted to obtain results earlier [6]. Cronbach's alpha is widely used to test the reliability of a survey with a value higher than 0.7 indicates high reliability. The value of the alpha reliability coefficient is between 0 and 1 . The closer to 1 means the set of questions is more reliable, stable, and consistent, and vice versa.

This research concludes primary sources, surveys, and interviews, to be explained through the secondary data. It is necessary to conduct such a procedure because of the disagreement from the respondents to reveal confidential data. The first key success factors for development is technical substitution. This factor will discuss the probability of both internal and external drivers or barriers from the industry to strive for a successful future. The second is technical drivers or barriers. It is talking not only about the conversion of technologies available and downstream processing of technologies but also about the accounts for the availability of technologies. The third is barriers application followed by cost barriers, and the last is raw material supply barriers. This study aims to identify the key factors which are necessary for new material development in food packaging. The expected results show that the key success factors are different from the abroad situation.

\section{CONCLUSION}

This study is conducted as a contribution to the development of new material in the context of a food production package. The government is expected to have a significant effect on the development of new material, with the public or consumer placed second.

\section{REFERENCES}

[1] S. Tariq, "Success factors for the adoption of bio-based packaging in EU food industry," p. 82, 2013.

[2] Purwoko P, Wibowo T. Fiscal Incentives And Disincentives To Reduce Plastic Waste In Indonesia. InASEAN/Asian Academic Society International Conference Proceeding Series 2018 (pp. 213 218). 
[3] Juliastuti SR, Hendrianie N, Ramadhan PJ, Satria DH. Microwave pyrolysis of multilayer plastic waste (LDPE) using zeolite catalyst. InAIP Conference Proceedings 2017 May 24 (Vol. 1840, No. 1, p. 110001). AIP Publishing LLC.

[4] Magnier L, Schoormans J, Mugge R. Judging a product by its cover: Packaging sustainability and perceptions of quality in food products. Food Quality and Preference. 2016 Oct 1;53:132-42.

[5] Hidayat YA, Kiranamahsa S, Zamal MA. A study of plastic waste management effectiveness in Indonesia industries. AIMS Energy. 2019 Jun 2;7(3):350.

[6] J. Collis and R. Hussey, Business Research: A Practical Guide for Undergraduate and Postgraduate Students, 4th ed. Palgrave Macmillan, 2014. 